\title{
Genes regulated by interferon- $\gamma$ in human uterine microvascular endothelial cells
}

\author{
KOTARO KITAYA, TADAHIRO YASUO, TAKESHI YAMAGUCHI, SHINJI FUSHIKI and HIDEO HONJO \\ Department of Obstetrics and Gynecology, Kyoto Prefectural University of Medicine, \\ 465 Kajii-cho, Kawaramachi-Hirokoji, Kamigyo-ku, Kyoto 602-8566, Japan
}

Received July 19, 2007; Accepted August 29, 2007

\begin{abstract}
Interferon (IFN)- $\gamma$ plays a critical role in murine uterine spiral artery remodeling for successful pregnancy. The effect of IFN- $\gamma$ on human uterine microvasculature, however, remains poorly understood. The aim of this study was to identify the genes regulated by IFN- $\gamma$ in human uterine microvascular endothelial cells. The effect of IFN- $\gamma$ on the gene expression profile in human uterine microvascular endothelial cells was evaluated by cDNA microarray analysis and quantitative real-time reverse transcriptase-polymerase chain reaction for the selected genes of interest. In vivo expression of the protein encoded by some of these genes in human uterine microvascular endothelial cells was evaluated by Western blotting and immunohistochemistry. Treatment with $10 \mathrm{ng} / \mathrm{ml} \mathrm{IFN}-\gamma$ for $4 \mathrm{~h}$ induced a significant $\geq 2$-fold change in 29 genes in pooled human uterine microvascular endothelial cells; a total of 20 genes were up-regulated, whereas nine genes were down-regulated. The genes significantly up-regulated included chemokines (CXCL9, CXCL10, CCL8, IL15RA, and CCL5), enzymes (GBP5, TAP1, CYP27B1, SOD2, MX1, CASP1, and PTGES), and transcription factors (TFAP2C,IRF1,NFE2L3). The genes significantly down-regulated following IFN- $\gamma$ treatment included cytokines/cytokine receptors $(C S F 2, I L 1 R 2$, and $S P P 1)$, and insulin-like growth factor binding proteins (WISP2 and IGFBP3). The results of the cDNA microarray analysis were confirmed by quantitative real-time reverse transcriptase-polymerase chain reaction for the selected 17 genes of interest. The immunoreactivity for the proteins encoded by IL15RA, IFI30, and MXI was detected in human uterine microvascular endothelial cells in vivo, whereas the immunoreactivity for CCNAI and $N Q O 1$ was not detectable. These results suggest that $\mathrm{IFN}-\gamma$ regulates the gene
\end{abstract}

Correspondence to: Dr Kotaro Kitaya, Department of Obstetrics and Gynecology, Kyoto Prefectural University of Medicine, 465 Kajii-cho, Kawaramachi-Hirokoji, Kamigyo-ku, Kyoto 602-8566, Japan

E-mail: kitaya@koto.kpu-m.ac.jp

Key words: interferon- $\gamma$, gene expression profile, human uterine microvascular endothelial cells expression involved in natural killer cell recruitment, embryo and trophoblast migration, endometrial decidualization, angiogenesis, angiostasis, and anti-viral infection in human uterine microvascular endothelial cells

\section{Introduction}

Efficient uterine blood supply to the implantation site is a prerequisite for successful embryo and placental development. After ovulation, the peripheral branches of the uterine arteries develop through the inner myometrium and whole endometrium in a helicoid form (defined as uterine spiral arteries) and nourish the uterine wall layers. If the embryo is implanted successfully into the endometrium, uterine spiral arteries further develop in the decidualized endometrium towards the fetal site to supply the maternal blood flow to intervillous spaces of the placenta. During human placentation, a cluster of cytotrophoblasts differentiate into the invasive phenotype in the cell column of the anchoring villi, migrate into the uterine spiral arteries, and replace the endothelial cells of the uterine spiral arteries. This remodeling of the uterine spiral arteries by invading trophoblasts leads to the loss of arterial contractility, which enables constant maternal blood flow into the intervillous spaces to support placental function (1).

Interferon (IFN)- $\gamma$, a cytokine produced by various cell types, shows a wide range of biological activities in mammalian species. Studies have revealed the potential roles of IFN- $\gamma$ in successful reproduction. In the murine uterus, IFN- $\gamma$ originates in leukocytes of natural killer cell lineage infiltrating decidua basalis, mesometrial triangle, and mesometrial lymphoid aggregates of pregnancy (transient lymphoid structures develop in the myometrium at the implantation sites surrounding the uterine arterial branches) (2). Pregnant mice lacking the IFN- $\gamma$ gene display impaired uterine spiral artery remodeling, endometrial decidualization, smaller litter size, and increased fetal losses, which resemble the histopathological and clinical findings seen in preeclampsia (3). These findings suggest that IFN- $\gamma$ modifies the gene expression in uterine microvessels, which is important for instability and remodeling of uterine microvasculature during pregnancy (2).

In humans, IFN- $\gamma$ is expressed in uterine intraepithelial lymphocytes and endometrial stromal polymorphonuclear neutrophils under nonpregnant conditions (4). After embryo 
implantation, IFN- $\gamma$ is also produced by CD16(-) natural killer cells infiltrating the decidualized endometrial stroma (5). IFN- $\gamma$ induces in vitro proliferation and differentiation of human uterine epithelial cells and endometrial stromal fibroblasts (6-8), and regulates the invasion of the extravillous trophoblasts into decidualized endometrium $(9,10)$. In contrast, the effect of IFN- $\gamma$ on human uterine microvasculature remains poorly understood.

This study was conducted to obtain a comprehensive view on the effect of IFN- $\gamma$ on the gene expression profile in human uterine microvascular endothelial cells. Using cDNA microarray analysis, we investigated the change in gene expression induced by IFN- $\gamma$ in these cells. We confirmed the results by quantitative real-time reverse transcriptasepolymerase chain reaction for the selected genes of interest. In addition, we investigated in vivo protein expression encoded by some of these genes in the human uterine microvascular endothelial cells.

\section{Materials and methods}

Antibodies and reagents. Mouse anti-human IFN- $\gamma$ receptor $\alpha$ chain monoclonal antibody (GIR-94, sc12775), goat antihuman IFN- $\gamma$ receptor $\beta$ chain polyclonal antibody (C-20, sc970), goat anti-human myxovirus resistance 1 (MX1) polyclonal antibody (D-14, sc34128), goat anti-interferoninducible protein 30 (IFI30) polyclonal antibody (T-18, sc21827), rabbit anti-cyclin A1 (CCNA1) polyclonal antibody (H432, sc751), mouse anti-NAD(P)H quinone oxidoreductase 1 (NQO1) monoclonal antibody (A180, sc32793), and the corresponding control isotype-matched immunoglobulin were purchased from Santa Cruz Biotechnology (Santa Cruz, CA). Blocking peptides for each antibody were also purchased from Santa Cruz Biotechnology. Goat antihuman interleukin-15 receptor $\alpha$ chain (IL15RA) polyclonal antibody (AF247) and recombinant human IL-15 receptor $\alpha$ chain/Fc chimera (147-IR, extracellular domain of IL-15 receptor $\alpha$ chain) were purchased from R\&D Systems (Minneapolis, MN).

Samples. Human myometrial and endometrial samples were obtained from 20 fertile women aged 32-45 years, who had undergone hysterectomy for cervical carcinoma in situ $(n=18)$ and cervical dysplasia $(n=2)$. Informed consent was obtained from each patient before the operation. They had regular menstrual cycles ranging from 28 to 35 days and were not receiving any hormonal treatment. None of these samples showed any pathological findings such as polyps, leiomyomas, adenomyosis or endometritis. Following the standard criteria for endometrial dating (11), 5, 4, 6, and 5 samples were classified into the proliferative phase, early secretory phase, mid-secretory phase, and late secretory phase, respectively. The samples were collected immediately after hysterectomy and washed in phosphate-buffered saline (PBS). A portion of the samples was fixed overnight in a $4 \%$ paraformaldehyde [in phosphate buffer ( $\mathrm{pH}$ 7.3)] and embedded in paraffin. The remainder was homogenized and solubilized in lysis buffer ( $2 \mu \mathrm{M}$ aprotinin, $50 \mu \mathrm{M}$ leupeptin, $125 \mu \mathrm{M}$ bestatin, and $25 \mu \mathrm{M}$ pepstatin A; Nacalai Tesque, Kyoto, Japan). The protein concentration in the soluble protein fraction was measured with a DC protein assay kit (Bio-Rad Laboratories, Hercules, CA). The soluble protein fraction was preserved at $-80^{\circ} \mathrm{C}$ until assay. This study was approved by the Kyoto Prefectural University of Medicine Institutional Review Board.

Cell culture. Pooled human uterine microvascular endothelial cells were purchased from Cambrex (Walkersville, MD). By immunostaining, $>98 \%$ of cells were CD34(+) and smooth muscle actin (-) throughout the cell culture and passage (Fig. 1A), which are consistent with the phenotypes of the endothelial cells (12). The soluble protein fraction was extracted from the cells using Trizol reagent (Invitrogen, Carlsbad, CA) according to the manufacturer's protocol. The expression of IFN- $\gamma$ receptor subunits was examined by immunoreactivity with $2 \mu \mathrm{g} / \mathrm{ml}$ anti-IFN- $\gamma$ receptor $\alpha$ or $B$ chain antibody. The cells were maintained in 6-well plates with $4 \mathrm{ml}$ phenol-red free medium 199 (Invitrogen) supplemented with $30 \mathrm{mM}$ HEPES buffer, 10\% charcoalstripped fetal calf serum, $100 \mathrm{IU} / \mathrm{ml}$ penicillin, $100 \mu \mathrm{g} / \mathrm{ml}$ streptomycin, and $2.5 \mu \mathrm{g} / \mathrm{ml}$ amphotericin B. The cells from passage 2-4 were treated with or without $10 \mathrm{ng} / \mathrm{ml}$ recombinant human IFN- $\gamma$ for 4 or $24 \mathrm{~h}$ and pooled from three different wells. The experiments were performed in triplicate.

Microarray analysis. Total RNA was extracted using Trizol reagent, purified using DNase (Invitrogen) and the RNeasy mini kit (Qiagen, Valencia, CA), and dissolved in RNase-free water. The purity and amount were measured by OD260/ OD280 absorbance ratio and electrophoresis on an agarose gel. First- and second-strand cDNAs were synthesized from $5 \mu \mathrm{g}$ total RNA using the oligodeoxythymidine 24 primer containing T7 promoter sequence (Qiagen). cRNA was synthesized from second-strand cDNA with aminoallyl-UTP (Applied Biosystems, Ambion, Foster City, CA) using Superscript RNA Amplification System (Invitrogen) and labeled with Cy-5 and Cy-3 (Qiagen). cRNA was hybridized to oligo DNA chip (Hitachi Human Chip ver. 1, Hitachi Life Science, Tokyo, Japan) overnight at $45^{\circ} \mathrm{C}$. The chips were scanned using ScanArray 5000 (GSI Lumonics, Billerica, MA). The image data were converted to the intensity value data and analyzed by subtracting the backgrounds using the QuantArray software (GSI Lumonics). The intensity values for DNA duplicate probes were averaged. Following normal globalization method, the data were subjected to serial pairwise comparisons. The relative intensity values $(\mathrm{Cy}-5 / \mathrm{Cy}-3)$ for the genes were statistically analyzed using DNASIS array ver. 2.6 (Hitachi Life Science). The one-way analysis of variance test was used to estimate the $\mathrm{p}$ value for every gene without the post-hoc test. Benjamini-Hochberg multiple testing correction was used for the false discovery rate (13).

Quantitative real-time reverse transcriptase-polymerase chain reaction. cDNA was synthesized from $2 \mu \mathrm{g}$ total RNA with $1 \mu \mathrm{g}$ of oligodeoxythymidine primers by $250 \mathrm{U}$ Superscript II reverse transcriptase (Invitrogen) in a final volume of $25 \mu 1$. This solution was subjected to polymerase chain reaction with a QuantiTect SYBR-Green polymerase chain reaction kit (Applied Biosystems) and the specific primers $(0.5 \mu \mathrm{M})$ for the genes of interest (Table I) following 
A
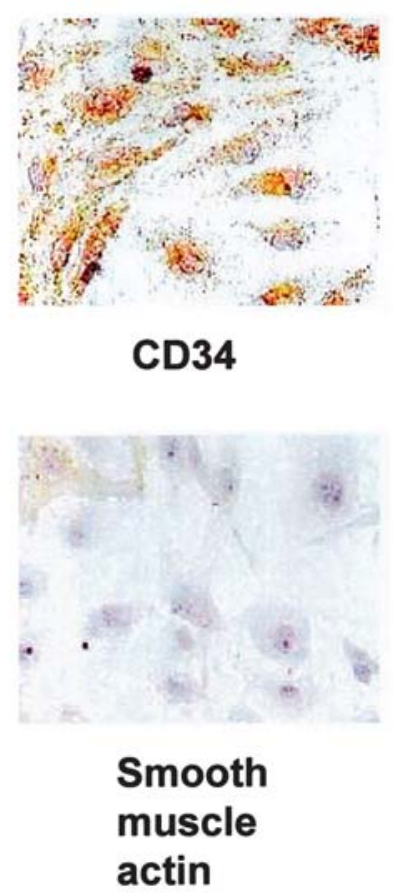

B

$\begin{array}{ll}\text { Human } & \text { Human } \\ \text { uterine } & \text { umbilical } \\ \text { micro- } & \text { vein } \\ \text { vascular } & \text { endothelial } \\ \text { endothelial } & \text { cells } \\ \text { cells } & \end{array}$

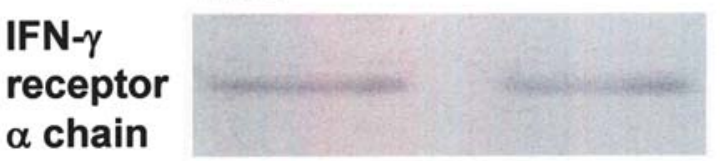

Figure 1. Characterization of cultured human uterine microvascular endothelial cells. (A) Immunocytochemistry for CD34 and smooth muscle actin expression in cells from passage 4. (B) Western blotting for IFN- $\gamma$ receptor $\alpha$ and $\beta$ chain expression. Human umbilical vein endothelial cells were used as a positive control.

the manufacturer's protocol. Each cycle consisted of denaturation $\left(30 \mathrm{sec}\right.$ at $\left.94^{\circ} \mathrm{C}\right)$, annealing $\left(30 \mathrm{sec}\right.$ at $\left.60^{\circ} \mathrm{C}\right)$, and elongation $\left(30 \mathrm{sec}\right.$ at $\left.72^{\circ} \mathrm{C}\right)$. As an internal control, human $R P L 19$, a less variable gene in expression levels in the human endometrium (14, and in this study) compared with other known housekeeping genes was simultaneously amplified under the same condition. We confirmed the specificity of the reaction by amplification of the RNA solution without reverse transcriptase and electrophoresis of the polymerase chain reaction products on an agarose gel. Fluorescent data were obtained during the annealing and elongation of each cycle using the ABI PRISM 7000 Sequence Detection System (Applied Biosystems). The sequence of the polymerase chain reaction products was confirmed with a Sequence Scanner ver. 1.0 (Applied Biosystems).

Western blot analysis. The myometrial and endometrial soluble protein fraction was separated by sodium dodecyl sulfate-polyacrylamide gel electrophoresis and electrotransferred to a polyvinylidene difluoride membrane (BioRad Laboratories). The membrane was incubated with $5 \%$ nonfat milk in Tris-buffered saline-T (containing $0.1 \mathrm{M} \mathrm{NaCl}$, $0.01 \mathrm{M}$ Tris, $0.1 \%$ Tween-20) to reduce nonspecific antibody binding. The membrane was then incubated with one of the following primary antibodies; anti-IL15RA $(2 \mu \mathrm{g} / \mathrm{ml})$, antiMX1 $(1 \mu \mathrm{g} / \mathrm{ml})$, anti-IFI30 $(2 \mu \mathrm{g} / \mathrm{ml})$, anti-CCNA1 $(4 \mu \mathrm{g} / \mathrm{ml})$ or anti-NQO1 $(10 \mu \mathrm{g} / \mathrm{ml})$. The control immunoglobulin was used to exclude background staining. After being washed, the membrane was incubated with a secondary antibody conjugated with horseradish peroxidase (1:10,000 dilution; Santa Cruz Biotechnology). Immunoreactivity was detected with enhanced chemiluminescence using ECL Plus detection kit (Amersham-Pharmacia, Uppsala, Sweden).

Immunohistochemistry. Fixed samples were embedded in paraffin and cut into $4-\mu \mathrm{m}$ sections. After being deparaffinized in xylene and rehydrated in a graded series of ethanol, sections were immersed in 3\% hydrogen peroxide for $5 \mathrm{~min}$ to block endogenous peroxidase and then incubated with PBS containing $10 \%$ fetal calf serum for $10 \mathrm{~min}$ at room temperature to suppress nonspecific antibody binding. In a moist chamber, sections were incubated with one of the following antibodies overnight at $4^{\circ} \mathrm{C}$; anti-IL15RA $(5 \mu \mathrm{g} /$ $\mathrm{ml})$, anti-MX1 $(10 \mu \mathrm{g} / \mathrm{ml})$, anti-IFI30 $(10 \mu \mathrm{g} / \mathrm{ml})$, or antiCCNA1 $(20 \mu \mathrm{g} / \mathrm{ml})$. To achieve optimal immunostaining, in some sections, microwave treatment of deparaffinized sections with $0.1 \mathrm{M}$ citrate buffer ( $\mathrm{pH}$ 6.0; Dako, Kyoto, Japan) was performed prior to the incubation with primary antibodies. The control isotype-matched immunoglobulin was used to exclude background staining. After being washed in PBS, the section was incubated with a LASB kit (Dako). Sections were washed and developed with diaminobenzidine (Dako).

\section{Results}

Genes significantly up- or down-regulated by IFN- $\gamma$ in human uterine microvascular endothelial cells. The immunoreactivity for IFN- $\gamma$ receptor $\alpha$ chain was detected at $90 \mathrm{kDa}$ as a single band in the human uterine microvascular endothelial cells (Fig. 1B). The immunoreactivity for IFN- $\gamma$ receptor $\beta$ chain was detected at $38 \mathrm{kDa}$ as a single band. 
Table I. Primer pairs used for quantitative real-time reverse transcriptase-polymerase chain reaction.

\begin{tabular}{|c|c|c|c|}
\hline Gene name & Forward primer & Reverse primer & $\begin{array}{l}\text { Prospected product } \\
\text { size (base pairs) }\end{array}$ \\
\hline Chemokine (C-X-C motif) ligand 9 (CXCL9) & ccaccgagatccttatcgaa & ctaaccgacttggctgcttc & 163 \\
\hline Chemokine (C-X-C motif) ligand 10 (CXCL10) & aggaacctccagtctcagca & caaaattggcttgcaggaat & 192 \\
\hline Interferon $\gamma$-inducible protein 30 (IFI30) & ccctcaggagtgtttgcttc & gatcatggggtggaattttg & 180 \\
\hline Intercellular adhesion molecule 1 (ICAMI) & ggctggagctgtttgagaac & actgtggggttcaacctctg & 202 \\
\hline Interleukin 15 receptor, $\alpha(I L 15 R A)$ & gactttgeccactctcttcg & ctgtggttcctgtggaaggt & 213 \\
\hline $\begin{array}{l}\text { Cytochrome } \mathrm{P} 450 \text {, family } 27 \text { subfamily } \mathrm{B} \text {, polypeptide } 1 \\
(C Y P 27 B 1)\end{array}$ & tgtttgcatttgctcagagg & ccgggagagctcatacagag & 227 \\
\hline Nuclear factor (erythroid-derived 2)-like 3 (NFE2L3) & tgcgcagaactgtcgtaaac & ttgactggcetaccttggtc & 201 \\
\hline $\begin{array}{l}\text { Myxovirus (influenza virus) resistance } 1 \text {, } \\
\text { interferon-inducible protein p78 (mouse) }(M X 1)\end{array}$ & acctacagctggetcctgaa & gcactcaagtcgtcagtcca & 201 \\
\hline Chemokine (C-C motif) ligand 5 (CCL5) & gaggcttcccetcactatcc & ctcaagtgatccacccacct & 155 \\
\hline $\begin{array}{l}\text { Caspase } 1 \text {, apoptosis-related cysteine protease } \\
\text { (interleukin } 1, B \text {, convertase) }(C A S P 1)\end{array}$ & ctcaggctcagaagggaatg & cgctgtaccccagattttgt & 221 \\
\hline Interferon-induced protein 44 (IFI44) & agcctgtgaggtccaagcta & ttgctcaaaaggcaaatcct & 188 \\
\hline Prostaglandin E synthase (PTGES) & catgtgagtccctgtgatgg & ctgcagcaaagacatccaaa & 173 \\
\hline $\begin{array}{l}\text { Gap junction protein, } \alpha 4,37 \mathrm{kDa} \\
\text { (connexin } 37)(G J A 4)\end{array}$ & cttcatgttggtggttgga & cggggaggtagaagaagacc & 174 \\
\hline Cyclin A1 (CCNAI) & ccaactactgcgaggaggac & gacatagcagcaccagtgga & 179 \\
\hline $\begin{array}{l}\text { Solute carrier family } 14 \text { (urea transporter), member } 1 \\
\text { (Kidd blood group) (SLC14AI) }\end{array}$ & gtcggcatggcaaactttat & ggcttgcaggtagaagatgc & 171 \\
\hline Insulin-like growth factor binding protein 3 (IGFBP3) & cagagactcgagcacagcac & gatgaccggggtttaaaggt & 194 \\
\hline NAD(P)H dehydrogenase, quinone $1(N Q O 1)$ & aaaggaccettccggagtaa & ttccatccttccaggatttg & 224 \\
\hline
\end{tabular}

Using cDNA microarray analysis, we examined the effect of IFN- $\gamma$ on 1,873 genes in the human uterine microvascular endothelial cells. Treatment of the cells with $10 \mathrm{ng} / \mathrm{ml}$ IFN- $\gamma$ for $4 \mathrm{~h}$ induced a significant $\geq 2$-fold change in 36 genes in experiment 1, 41 genes in experiment 2, and 37 genes in experiment 3 . The number of genes that displayed a significant $\geq 2$-fold change $(\mathrm{p}<0.05)$ in all three independent experiments was 29 . Of these 29 genes, a total of 20 genes were up-regulated, whereas nine genes were down-regulated (Table II). The genes significantly up-regulated included chemokines (CXCL9, CXCL10, CCL8, IL15RA, and CCL5), enzymes (GBP5, TAP1, CYP27B1, SOD2, MX1, CASP1, and $P T G E S)$, and transcription factors (TFAP2C, IRF1, NFE2L3). The genes significantly down-regulated following IFN- $\gamma$ treatment included cytokines/cytokine receptors (CSF2, $I L 1 R 2$, and $S P P 1)$, and insulin-like growth factor binding proteins (WISP2 and IGFBP3). Following an additional 20-h treatment, 4 genes $(C S H 2, I C A M 1, T A P 1$, and IL15RA) were further up-regulated, whereas 2 genes (WISP2 and IGFBP3) were further down-regulated.

To confirm the results of the microarray analysis, we selected the genes of interest for quantitative real-time reverse transcriptase-polymerase chain reaction. Of the 29 genes significantly up- or down-regulated by IFN- $\gamma$, we included 17 genes whose encoding protein expression was confirmed in vivo (CXCL9, CXCL10, ICAM1, CYP27B1, NFE2L3, CCL5, CASP1, PTGES, GJA4, and IGFBP3), or remained undetermined (IFI30, IL15RA, MX1, IFI44, CCNA1, SLC14A1, and NQO1). Treatment of human uterine microvascular endothelial cells with $10 \mathrm{ng} / \mathrm{ml} \mathrm{IFN-} \gamma$ for $4 \mathrm{~h}$ significantly up-regulated the expression of CXCL9 (mean fold change, 9.4-fold), CXCL10 (8.3-fold), IFI3O (4.5-fold), ICAM1 (4.1-fold), IL15RA (4.6-fold), CYP27B1 (3.3-fold), NFE2L3 (2.9-fold), MX1 (2.6-fold), CCL5 (2.8-fold), CASP1 (2.6-fold), IFI44 (2.3-fold), PTGES (2.7-fold), and GJA4 (2.3-fold), and down-regulated the expression of IGFBP3 (0.39-fold), CCNA1 (0.37-fold), SLC14A1 (0.42-fold), and NQO1 (0.41-fold). The results were consistent with the results of the microarray analysis.

In vivo protein expression encoded by genes regulated by IFN- $\gamma$ in human uterine microvascular endothelial cells. To clarify whether the genes up- or down-regulated by IFN- $\gamma$ were expressed in vivo in human uterine microvascular endothelial cells at a protein level, we examined the expression of five proteins (IL15RA, IFI30, MX1, CCNA1, and NQO1), whose encoding protein expression in these cells remains undetermined. By Western blotting, the immunoreactivity for 
Table II. Genes up- or down-regulated in human uterine microvascular endothelial cells following $10 \mathrm{ng} / \mathrm{ml} \mathrm{recombinant}$ human IFN- $\gamma$ treatment for 4 and 24 h. ${ }^{\text {a }}$

\begin{tabular}{|c|c|c|c|}
\hline Gene name (gene symbol) & $\begin{array}{c}\text { GenBank } \\
\text { accession no. }\end{array}$ & Gene ontology & Fold change \\
\hline
\end{tabular}

Up-regulated genes

Chemokine (C-X-C motif)

Chemokine

11.67

8.15

ligand 9 (CXCL9)

Chemokine (C-X-C motif)

ligand 10 (CXCL1O)

X02530 cAMP-dependent protein

10.49

Chemokine (C-C motif)

X99886

kinase regulator, chemokine

ligand 8 (CCL8)

Chemokine, heparin binding,

signal transducer

Chorionic somatomammotropin

Growth hormone, structural constituent of chorion

hormone 2 (CSH2)

V00573

Guanylate binding protein 5 (GBP5)

Interferon $\gamma$-inducible protein 30 (IFI30)

Transcription factor AP-2 $\gamma($ TFAP2C)

Intercellular adhesion molecule 1 (CD54), human rhinovirus receptor (ICAMI)

Transporter 1, ATP-binding cassette, sub-family B (MDR/TAP) (TAPl)

GTPase

AF430642

Unknown

J03909

NM_003222

Transcription factor

NM_000201

Adhesion molecule, transmembrane receptor

NM_000593

ATPase, Coupled to transmembrane movement of substances, oligopeptide transporter, protein heterodimerization

Interleukin 15 receptor, $\alpha(I L 15 R A)$

U31628

Cytochrome P450, family 27 subfamily B, polypeptide 1 (CYP27B1)

Superoxide dismutase 2,

AB006987

Cytokine receptor

Calcidiol 1-monooxygenase,

M36693

mitochondrial (SOD2)

Interferon regulatory factor 1 (IRF 1$)$

Nuclear factor (erythroid-derived 2)-like 3

(NFE2L3)

Myxovirus (influenza virus) resistance 1, interferon-inducible protein p78 (mouse) $(M X I)$

Chemokine (C-C motif) ligand 5 (CCL5)

Caspase 1, apoptosis-related cysteine protease (interleukin $1, \beta$, convertase) (CASPI)

NM_002198 metal ion binding, oxygen binding metal ion binding, oxidoreductase

AB010812

Transcription factor

AF043341

Chemokine

Caspase activator, caspase,

cysteine-type peptidase, signal transducer

Interferon-induced protein 44 (IFI44)

D28915

Unknown details

(response to virus)

AF010316

Isomerase,

prostaglandin-E synthase

Gap junction protein, $\alpha 4,37 \mathrm{kDa}$

M96789

Connexin channel

Down-regulated genes

Colony stimulating factor 2

M11734

Cytokine, granulocyte macrophage

(granulocyte-macrophage) (CSF2) 
Table II. Continued.

\begin{tabular}{|c|c|c|c|c|}
\hline \multirow[t]{2}{*}{ Gene name (gene symbol) } & \multirow{2}{*}{$\begin{array}{c}\text { GenBank } \\
\text { accession no. }\end{array}$} & \multirow[t]{2}{*}{ Gene ontology } & \multicolumn{2}{|c|}{ Fold change } \\
\hline & & & $4 \mathrm{~h}$ & $24 \mathrm{~h}$ \\
\hline $\begin{array}{l}\text { WNT1 inducible signaling pathway } \\
\text { protein } 2 \text { (WISP } 2)\end{array}$ & AF100780 & Insulin-like growth factor binding & 0.20 & 0.17 \\
\hline Cyclin A1 (CCNAI) & U66838 & $\begin{array}{l}\text { Cell division, meiosis, mitosis, } \\
\text { regulation of cyclin-dependent } \\
\text { protein kinase }\end{array}$ & 0.22 & 0.33 \\
\hline Interleukin 1 receptor, type II (ILIR2) & X59770 & $\begin{array}{l}\text { Cytokine receptor, } \\
\text { blocking receptor activity }\end{array}$ & 0.24 & 0.34 \\
\hline $\begin{array}{l}\text { Wingless-type MMTV integration site family } \\
\text { member } 7 \mathrm{~A}(W N T 7 A)\end{array}$ & D83175 & $\begin{array}{l}\text { Receptor binding, } \\
\text { signal transducer activity }\end{array}$ & 0.25 & 0.42 \\
\hline $\begin{array}{l}\text { Solute carrier family } 14 \text { (urea transporter), } \\
\text { member } 1 \text { (Kidd blood group) (SLC14AI) }\end{array}$ & ВC040128 & Urea transporter & 0.27 & 0.38 \\
\hline $\begin{array}{l}\text { Insulin-like growth factor binding } \\
\text { protein } 3(I G F B P 3)\end{array}$ & NM_001013398 & $\begin{array}{l}\text { Insulin-like growth factor binding, } \\
\text { metal ion binding, protein tyrosine } \\
\text { phosphatase activator }\end{array}$ & 0.34 & 0.31 \\
\hline NAD(P)H dehydrogenase, quinone 1 (NQOI) & M81600 & $\begin{array}{l}\text { NAD }(\mathrm{P}) \mathrm{H} \text { dehydrogenase (quinone), } \\
\text { cytochrome-b5 reductase, oxidoreductase }\end{array}$ & 0.36 & 0.52 \\
\hline $\begin{array}{l}\text { Secreted phosphoprotein } 1 \\
\text { (osteopontin, bone sialoprotein I, } \\
\text { early T-lymphocyte activation 1) (SPPl) }\end{array}$ & NM_001040058 & $\begin{array}{l}\text { Cytokine, growth factor, } \\
\text { integrin binding, protein binding }\end{array}$ & 0.38 & 0.48 \\
\hline
\end{tabular}

aThe genes showing a significant $\geq 2$-fold change in all three independent experiments are listed. The fold change indicates the mean value of three independent experiments.

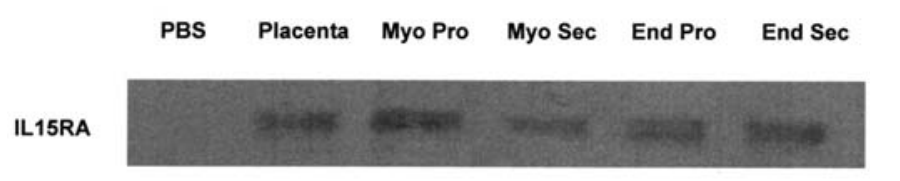

MX1

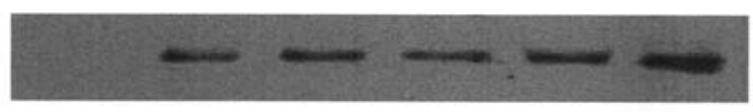

IFI30

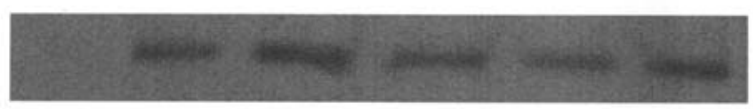

CCNA1

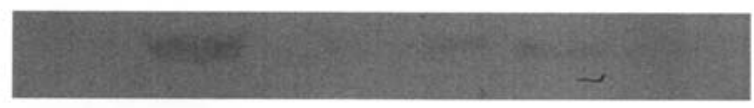

NQ01

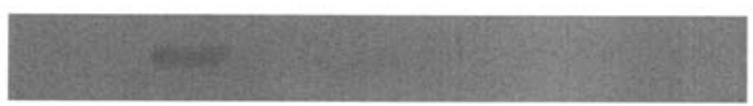

Figure 2. Representative Western blotting for IL15RA, IFI30, MX1, CCNA1, and NQO expression in the soluble protein fraction extracted from myometrial (Myo) and endometrial (End) samples in the proliferative phase (Pro) and secretory phase $(\mathrm{Sec})$. Protein extracts from placental tissue were used as a positive control.
IL15RA (55 kDa), IFI30 (30 kDa), and MX1 (75 kDa) was detected in the soluble protein fraction extracted from human myometrial and endometrial samples as well as the positive control placental tissue. The immunoreactivity for CCNA1 $(54 \mathrm{kDa})$ was detected in the endometrium in the proliferative phase at a very low level. The immunoreactivity for NQO1 was not detectable in any samples examined (Fig. 2).

To identify the localization of these proteins in the human myometrium and endometrium, we performed immunohistochemistry using paraffin-embedded sections. The immunoreactivity for IL15RA, MX1, and IFI30 was detected in the cytoplasm of the stromal and endothelial cells in the myometrium and in the cytoplasm of the epithelial, stromal, and endothelial cells in the endometrium (Fig. 3A and C-G). The immunoreactivity was blocked by immunoabsorption test (Fig. 3B). The immunostaining intensity for IL15RA was greater in the endothelial and epithelial cells than in the stromal cells. The immunostaining intensity for MX1 and IFI30 was greater in the functional layer of the endometrium than in the basal layer of the endometrium and the myometrium. In the proliferative phase, the immunoreactivity for CCNA1 was detected in $<10 \%$ of the endometrial epithelial cells and $<1 \%$ of the endometrial stromal cells, but not detected in the endometrial microvascular endothelial cells (Fig. 3H). 


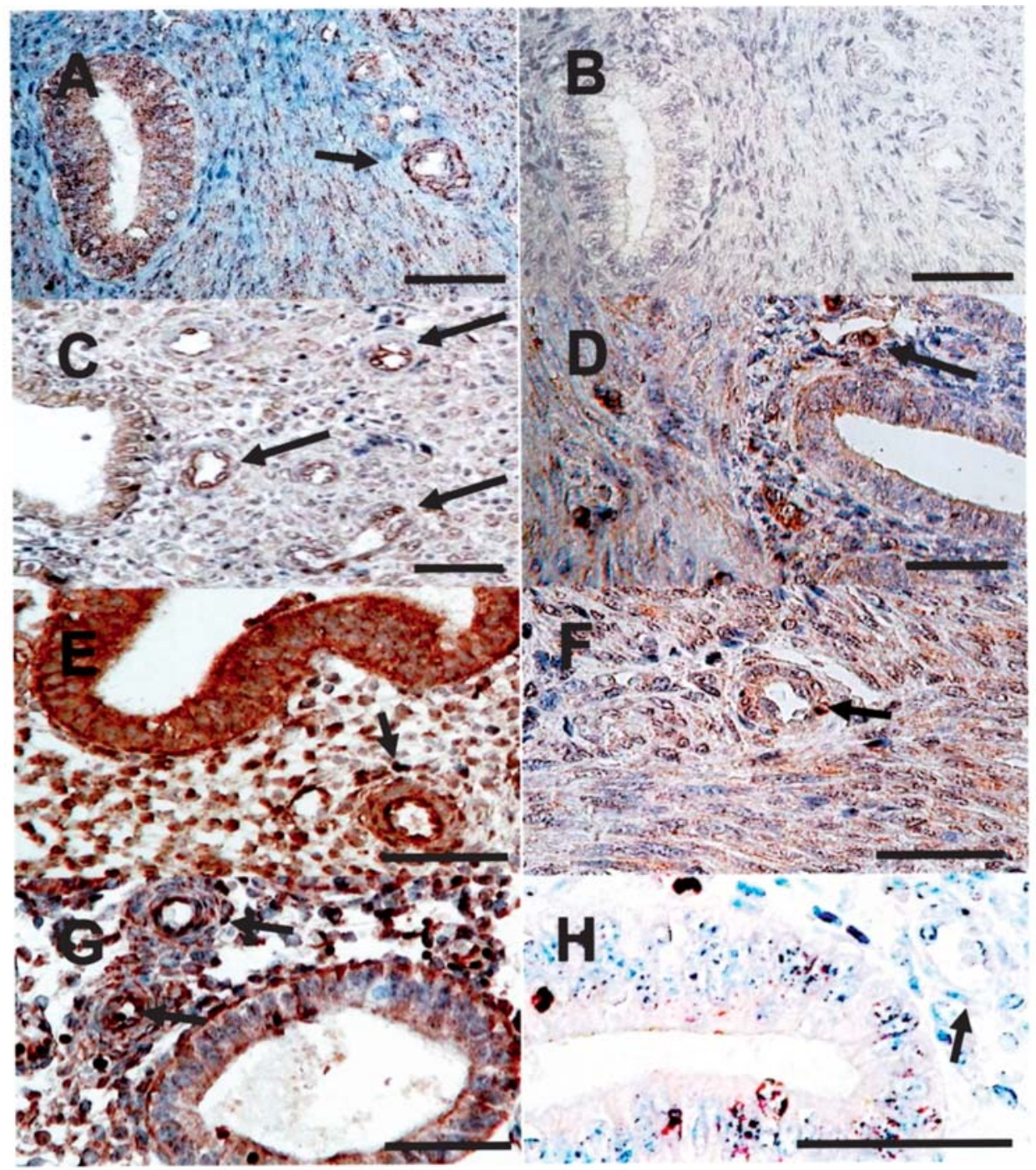

Figure 3. Representative immunohistochemistry for IL15RA (A, C), IFI30 (D, E), MX1 (F, G), and CCNA1 (H). Scale bars, $50 \mu \mathrm{m}$. Immunoabsorption test (B, serial section to A) confirmed the specificity of the immunostaining. Basal layer of endometrium and adjacent myometrium (A, B, D and F). Functional layer of endometrium $(\mathrm{C}, \mathrm{E}, \mathrm{G}$, and $\mathrm{H})$. The arrows indicate the microvessels.

\section{Discussion}

Using cDNA microarray analysis and quantitative real-time reverse transcriptase-polymerase chain reaction, we identified the genes up- or down-regulated by IFN- $\gamma$ in human uterine microvascular endothelial cells. Treatment of the cells with $10 \mathrm{ng} / \mathrm{ml} \mathrm{IFN-} \gamma$ for $4 \mathrm{~h}$ induced a significant $\geq 2$-fold change in more than 35 genes in each experiment. We narrowed the number of genes down to 29 which showed a significant $\geq 2$-fold change in all three independent experiments.

The gene cluster that was most highly up-regulated was the chemokines including CXCL9, CXCL10, CCL8, CCL5, and IL15RA. CXCL9, CXCL10, and CCL5 are expressed at the protein level in human endometrial microvascular endothelial cells $(15,16)$, while CCL8 is not expressed in these cells in vivo (17). In this study, we first demonstrated that IL15RA is expressed in uterine microvascular endothelial cells. CXCL9, CXCL10, CCL5, and the soluble form of protein IL15RA have strong chemotactic activities for
CD16(-) natural killer cells, which acutely increase in number in secretory phase endometrium (18-21). In this context, ICAMI, an adhesion molecule which is expressed in endometrial microvascular endothelial cells and plays a critical role in leukocyte tight adhesion to endothelial cells (22), was also significantly up-regulated by IFN- $\gamma$. IFN- $\gamma$ is known to induce selective transendothelial migration of peripheral blood CD16(-) natural killer cells in vitro (23). It is likely that IFN- $\gamma$ plays a role in transendothelial migration of CD16(-) natural killer cells across endometrial microvascular endothelial cells by enhancing the expression of these genes.

Some chemokines also have a potential chemotactic activity for embryonic cells. For example, CCL5 is a chemoattractant for human invading trophoblasts and blastocysts $(24,25)$, whereas CXCL10 shows a chemotactic activity for murine blastocysts (26). Human endometrial perivascular stromal cells express smooth muscle actin and have contractile activity, which are characteristic of myofibroblasts $(12,27)$. These cells show marked proliferation in 
response to progesterone and spread in the endometrial stroma (28). CXCL9 and CXCL1O can stimulate the proliferation of myofibroblast-like renal perivascular cells (29). These chemokines may be involved in the process of decidualization.

Several genes encoding enzymes (GBP5, TAP1, $C Y P 27 B 1, S O D 2, M X 1, C A S P 1$, and $P T G E S)$ were also significantly up-regulated by IFN- $\gamma$. $C Y P 27 B 1$ is the gene encoding 1,25-dihydroxyvitamin $\mathrm{D}_{3} 1 \alpha$-hydroxylase. This enzyme catalyzes the synthesis of 1,25-dihydroxyvitamin $\mathrm{D}_{3}$ which exerts immunosuppressive effects on CD16(-) natural killer cells in the endometrium $(30,31)$. The active form of this enzyme is expressed in the endothelial cells in the decidualized endometrium (30). The proteins encoded by CASP 1 and PTGES are also expressed in uterine microvascular endothelial cells in vivo $(32,33)$, while GBP5, TAP1, and SOD2 are not expressed (34-36). The role of CASP1 and $P T G E S$ in angiogenesis is speculated. For example, interleukin-1ß, which is synthesized by caspase 1 (protein encoded by $C A S P 1$ ), acts as an angiogenic growth factor (37). Similarly, prostaglandin E, which is synthesized by prostaglandin E synthase (protein encoded by PTGES), can induce vasodilation and angiogenesis (38).

IFN- $\gamma$ up-regulated the genes CXCL9 and CXCL10 for angiostasis. In addition to chemotactic activity, $C X C L 9$ and CXCL10 display angiostatic activity through a protein kinase A-mediated inhibition of m-calpain (39). The downregulation of several genes for angiogenesis, such as $C S F 2$, $S P P 1$, and $I L I R 2$ is in agreement with these findings. Indeed, $C S F 2, S P P 1$, and $I L 1 R 2$ are not expressed in uterine microvascular endothelial cells in vivo (40-42), suggesting the involvement of IFN- $\gamma$ in the functional regulation of these genes. CCNA1 is the cell cycle promoter gene important for DNA synthesis and germ cell meiosis (43). A recent study showed the potential role of CCNAl in the proliferation of human endometrial epithelial and stromal cells (44). In this study, CCNA1 was not detectable in the uterine microvascular endothelial cells. Thus, IFN- $\gamma$ probably contributes to the uterine microvasculature integrity by regulating the balance between angiogenesis and angiostasis.

The transcription factors, TFAP $2 C, I R F 1$, and NFE2L3 were up-regulated by IFN- $\gamma$. TFAP $2 C$ and IRF 1 are not expressed in uterine microvascular endothelial cells in vivo (45-47). NFE2L3 has been suggested to play a potential role in placental gene expression and development (48). Interestingly, a previous study demonstrated that NFE2L3 is a negative regulator of NAD(P)H dehydrogenase NQOI (49). We found that IFN- $\gamma$ down-regulated NQOI expression in the uterine microvascular endothelial cells and NQO1 was not expressed in these cells in vivo. These findings suggest that IFN- $\gamma$ modulates the expression status of NFE2L3 and NQO1 in uterine microvascular endothelial cells.

Also up-regulated were the genes for anti-viral infection IFI30 and MX1. IFI30 is a lysosomal protein that has a potential to induce CD8(+) T cell expansion against foreign antigens (50), while $M X 1$ plays an active role against influenza A virus and rhabdovirus (51). We detected both proteins in the uterine microvascular endothelial cells.

IFN- $\gamma$ down-regulated two genes for insulin growth factor binding, WISP2 and IGFBP3. WISP2 is not expressed in human uterine microvascular endothelial cells at the protein level, whereas the protein encoded by IGFBP3 is expressed in the myometrial microvascular endothelial cells in vivo, but not in endometrial microvascular endothelial cells (52). The role of $I G F B P 3$ in endothelial cells remains controversial; some investigators proposed the potential role of this gene in the growth of endothelial cells (53), while others found an inhibitory effect (54). The role of IGFBP3 in myometrial endothelial cells remains unclear.

In this study, we identified the genes regulated by IFN- $\gamma$ in human uterine microvascular endothelial cells in vitro. IFN- $\gamma$ induced the genes involved in natural killer cell recruitment, embryo and trophoblast migration, endometrial decidualization, angiogenesis, angiostasis, and anti-viral infection. These findings suggest that IFN- $\gamma$ modulates gene expression in human uterine microvascular endothelial cells, which plays an important role in embryo implantation and placentation.

\section{References}

1. Pijnenborg R, Vercruysse L and Hanssens M: The uterine spiral arteries in human pregnancy: facts and controversies. Placenta 27: 939-958, 2006.

2. Ashkar AA, Santo JPD and Croy BA: Interferon- $\gamma$ contributes to initiation of uterine vascular modification, decidual integrity, and uterine natural killer cell maturation during normal murine pregnancy. J Exp Med 192: 259-270, 2000.

3. Zhou Y, Damsky CH and Fisher SJ: Preeclampsia is associated with failure of human cytotrophoblasts to mimic a vascular adhesion phenotype. One cause of defective endovascular invasion in this syndrome? J Clin Invest 99: 2152-2164, 1997.

4. Yeaman GR, Collins JE, Currie JK, Guyre PM, Wira CR and Fanger MW: IFN- $\gamma$ is produced by polymorphonuclear neutrophils in human uterine endometrium and by cultured peripheral blood polymorphonuclear neutrophils. J Immunol 160: 5145-5153, 1998.

5. Saito S, Nishikawa K, Morii T, et al: Cytokine production by CD16- CD56 $6^{\text {bright }}$ natural killer cells in the human early pregnancy decidua. Int Immunol 5: 559-563, 1993.

6. Tabibzadeh S: Regulatory roles of IFN-gamma in human endometrium. Ann NY Acad Sci 734: 1-6, 1994.

7. Kai K, Nasu K, Nakamura S, Fukuda J, Nishida M and Miyakawa I: Expression of interferon- $\gamma$-inducible protein-10 in human endometrial stromal cells. Mol Hum Reprod 8: 176-180, 2002.

8. Hirota Y, Osuga Y, Koga K, et al: The expression and possible roles of chemokine CXCL11 and its receptor CXCR3 in the human endometrium. J Immunol 177: 8813-8821, 2006.

9. Lash GE, Otun HA, Innes BA, et al: Interferon- $\gamma$ inhibits extravillous trophoblast cell invasion by a mechanism that involves both changes in apoptosis and protease levels. FASEB J 20: 2512-2518, 2006.

10. Hu Y, Dutz JP, MacCalman CD, Yong P, Tan R and von Dadelszen P: Decidual NK cells alter in vitro first trimester extravillous cytotrophoblast migration: a role for IFN- $\gamma$. J Immunol 177: 8522-8530, 2006.

11. Noyes RW, Hertig AT and Rock J: Dating the endometrial biopsy. Fertil Steril 35: 751-754, 1950.

12. Oliver C, Montes MJ, Galindo JA, et al: Human decidual stromal cells express alpha-smooth muscle actin and show ultrastructural similarities with myofibroblasts. Hum Reprod 14: 1599-1605, 1999.

13. Benjamini Y and Hochberg Y: Controlling the false discovery rate: A practical and powerful approach to multiple testing. J R Stat Soc B 57: 289-300, 1995.

14. Talbi S, Hamilton AE, Vo KC, et al: Molecular phenotyping of human endometrium distinguishes menstrual cycle phases and underlying biological processes in normo-ovulatory women. Endocrinology 147: 1097-1121. 2006.

15. Kitaya K, Nakayama T, Daikoku N, Fushiki S and Honjo H: Spatial and temporal expression of ligands for CXCR3 and CXCR4 in human endometrium. J Clin Endocrinol Metab 89: 2470-2476, 2004. 
16. Caballero-Campo P, Dominguez F, Coloma J, et al: Hormonal and embryonic regulation of chemokines IL- 8 , MCP-1 and RANTES in the human endometrium during the window of implantation. Mol Hum Reprod 8: 375-384, 2002.

17. Hampton AL, Rogers PA, Affandi B and Salamonsen LA: Expression of the chemokines, monocyte chemotactic protein (MCP)-1 and MCP-2 in endometrium of normal women and Norplant users, does not support a central role in macrophage infiltration into endometrium. J Reprod Immunol 49: 115-132, 2001.

18. Campbell JJ, Qin S, Unutmaz D, et al: Unique subpopulations of CD56 ${ }^{+} \mathrm{NK}$ and NK-T peripheral blood lymphocytes identified by chemokine receptor expression repertoire. J Immunol 166 : 6477-6482, 2001

19. Kitaya K, Yamaguchi $\mathrm{T}$ and Honjo $\mathrm{H}$ : Central role of interleukin-15 in postovulatory recruitment of peripheral blood CD16(-) natural killer cells into human endometrium. J Clin Endocrinol Metab 90: 2932-2940, 2005.

20. Kitaya K, Yasuda J, Yagi I, Tada Y, Fushiki S and Honjo H: IL-15 expression at human endometrium and decidua. Biol Reprod 63: 683-687, 2000.

21. Mortier E, Quemener A, Vusio P, et al: Soluble interleukin-15 receptor $\alpha(\mathrm{IL}-15 \mathrm{R} \alpha)$-sushi as a selective and potent agonist of IL-15 action through IL-15Rß/ $\gamma$. Hyperagonist IL-15 x IL-15R $\alpha$ fusion proteins. J Biol Chem 281: 1612-1619, 2006

22. Schatz F, Krikun G, Baergen RN, Critchley HO, Kuczynski E and Lockwood CJ: Intercellular adhesion molecule-1 expression in human endometrium: implications for long term progestin only contraception. Reprod Biol Endocrinol 4: 2, 2006.

23. Berman ME, Xie Y and Muller WA: Roles of platelet/ endothelial cell adhesion molecule-1 (PECAM-1, CD31) in natural killer cell transendothelial migration and $B 2$ integrin activation. J Immunol 156: 1515-1524, 1996.

24. Sato Y, Higuchi T, Yoshioka S, Tatsumi K, Fujiwara H and Fujii S: Trophoblasts acquire a chemokine receptor, CCR1, as they differentiate towards invasive phenotype. Development 130: 5519-5532, 2003.

25. Dominguez F, Galan A, Martin JJ, Remohi J, Pellicer A and Simon C: Hormonal and embryonic regulation of chemokine receptors CXCR1, CXCR4, CCR5 and CCR2B in the human endometrium and the human blastocyst. Mol Hum Reprod 9: 189-198, 2003.

26. Nagaoka K, Nojima H, Watanabe F, et al: Regulation of blastocyst migration, apposition, and initial adhesion by a chemokine, interferon gamma-inducible protein $10 \mathrm{kDa}$ (IP-10), during early gestation. J Biol Chem 278: 29048-29056, 2003.

27. Kimatrai M, Oliver C, Abadia-Molina AC, Garcia-Pacheco JM and Olivares EG: Contractile activity of human decidual stromal cells. J Clin Endocrinol Metab 88: 844-849, 2003.

28. Kelly RW, King AE and Critchley HO: Inflammatory mediators and endometrial function: focus on the perivascular cell. J Reprod Immunol 57: 81-89, 2002.

29. Bonacchi A, Romagnani P, Romanelli RG, et al: Signal transduction by the chemokine receptor CXCR3: activation of Ras/ERK, Src, and phosphatidylinositol 3-kinase/Akt controls cell migration and proliferation in human vascular pericytes. J Biol Chem 276: 9945-9954, 2001

30. Zehnder D, Evans KN, Kilby MD, et al: The ontogeny of 25hydroxyvitamin $\mathrm{D}_{3} 1 \alpha$-hydroxylase expression in human placenta and decidua. Am J Pathol 161: 105-114, 2002.

31. Evans KN, Nguyen L, Chan J, et al: Effects of 25-hydroxyvitamin $\mathrm{D}_{3}$ and 1,25-dihydroxyvitamin $\mathrm{D}_{3}$ on cytokine production by human decidual cells. Biol Reprod 75: 816-822, 2006.

32. Simon C, Piquette GN, Frances A and Polan ML: Localization of interleukin-1 type I receptor and interleukin-1B in human endometrium throughout the menstrual cycle. J Clin Endocrinol Metab 77: 549-555, 1993.

33. Milne SA, Perchick GB, Boddy SC and Jabbour HN: Expression, localization, and signaling of $\mathrm{PGE}_{2}$ and EP2/EP4 receptors in human nonpregnant endometrium across the menstrual cycle. J Clin Endocrinol Metab 86: 4453-4459, 2001.

34. Fellenberg F, Hartmann TB, Dummer R, Usener D, Schadendorf D and Eichmüller S: GBP-5 splicing variants: New guanylate-binding proteins with tumor-associated expression and antigenicity. J Invest Dermatol 122: 1510-1517, 2004.
35. Koshiyama M, Yoshida M, Fujii H, et al: Expression of multidrug resistance-associated protein in endometrial carcinomas: correlation with clinicopathology and prognosis. Ann Diagn Pathol 3: 81-87, 1999.

36. Ota H, Igarashi S, Hatazawa J and Tanaka T: Immunohistochemical assessment of superoxide dismutase expression in the endometrium in endometriosis and adenomyosis. Fertil Steril 72: 129-134, 1999.

37. Naldini A, Leali D, Pucci A, et al: IL-1B mediates the proangiogenic activity of osteopontin-activated human monocytes. J Immunol 177: 4267-4270, 2006.

38. Gullino PM: Prostaglandins and gangliosides of tumor microenvironment: their role in angiogenesis. Acta Oncol 34: 439-441, 1995.

39. Bodnar RJ, Yates CC and Wells A: IP-10 blocks vascular endothelial growth factor-induced endothelial cell motility and tube formation via inhibition of calpain. Circ Res 98: 617-625, 2006.

40. Sharpe-Timms KL, Bruno PL, Penney LL and Bickel JT: Immunohistochemical localization of granulocyte-macrophage colony-stimulating factor in matched endometriosis and endometrial tissues. Am J Obstet Gynecol 171: 740-745, 1994.

41. Apparao KB, Murray MJ, Fritz MA, et al: Osteopontin and its receptor $\alpha_{v} \beta_{3}$ integrin are coexpressed in the human endometrium during the menstrual cycle but regulated differentially. J Clin Endocrinol Metab 86: 4991-5000, 2001.

42. Boucher A, Kharfi A, Al-Akoum M, Bossu P and Akoum A: Cycle-dependent expression of interleukin-1 receptor type II in the human endometrium. Biol Reprod 65: 890-898, 2001.

43. Liu D, Matzuk MM, Sung WK, Guo Q, Wang $P$ and Wolgemuth DJ: Cyclin A1 is required for meiosis in the male mouse. Nat Genet 20: 377-380, 1998.

44. Niklaus AL, Aubuchon M, Zapantis G, et al: Assessment of the proliferative status of epithelial cell types in the endometrium of young and menopausal transition women. Hum Reprod 22: $1778-1788,2007$

45. Li M, Wang Y, Yu Y, et al: The human transcription factor activation protein-2 $\gamma$ (AP-2 $\gamma$ ): gene structure, promoter, and expression in mammary carcinoma cell lines. Gene 301: 43-51, 2002

46. Jabbour HN, Critchley HO, Yu-Lee LY and Boddy SC: Localization of interferon regulatory factor-1 (IRF-1) in nonpregnant human endometrium: expression of IRF-1 is upregulated by prolactin during the secretory phase of the menstrual cycle. J Clin Endocrinol Metab 84: 4260-4265, 1999.

47. Kitaya K, Yasuda J, Fushiki S and Honjo H: Localization of interferon regulatory factor- 1 in human endometrium throughout the menstrual cycle. Fertil Steril 75: 992-996, 2001.

48. Chenais B, Derjuga A, Massrieh W, et al: Functional and placental expression analysis of the human NRF3 transcription factor. Mol Endocrinol 19: 125-137, 2005.

49. Sankaranarayanan K and Jaiswal AK: Nrf3 negatively regulates antioxidant-response element-mediated expression and antioxidant induction of $\mathrm{NAD}(\mathrm{P}) \mathrm{H}$ : quinone oxidoreductase 1 gene. J Biol Chem 279: 50810-50817, 2004.

50. Mason RD, Bowmer MI, Howley CM and Grant MD: Crossreactive cytotoxic $\mathrm{T}$ lymphocytes against human immunodeficiency virus type 1 protease and gamma interferon-inducible protein 30. J Virol 79: 5529-5536, 2005.

51. Pavlovic J and Staeheli P: The antiviral potentials of Mx proteins. J Interferon Res 11: 215-219, 1991.

52. Tang XM, Rossi MJ, Masterson BJ and Chegini N: Insulin-like growth factor I (IGF-I), IGF-I receptors, and IGF binding proteins 1-4 in human uterine tissue: tissue localization and IGF-I action in endometrial stromal and myometrial smooth muscle cells in vitro. Biol Reprod 50: 1113-1125, 1994.

53. Granata R, Trovato L, Lupia E, et al: Insulin-like growth factor binding protein-3 induces angiogenesis through IGF-I- and SphK1-dependent mechanisms. J Thromb Haemost 5: 835-845, 2007.

54. Liu B, Lee KW, Anzo M, et al: Insulin-like growth factorbinding protein-3 inhibition of prostate cancer growth involves suppression of angiogenesis. Oncogene 26: 1811-1819, 2007. 